\title{
EFFECT OF WATER HYACINTH (EICHHORNIA CRASSIPES) ROOTS ON SOME HEAVY METALS DISORDERS IN RATS
}

\author{
By \\ Mohamed Sabry Abdelbaky \\ Nutrition and Food Science Dept., \\ Faculty of Home Economics, \\ Helwan University
}

Research Gournal Specific Education

Faculty of Specific Education

gMansoura University

ISSUE NO. 26, YULY. 2012

مجلة بحوث التربية النوعية - جامعة المنصورة

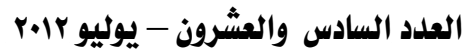


Effect of water hyacinth (Eichhornia crassipes) roots on some heavy metals disorders

7 .. 


\title{
EFFECT OF WATER HYACINTH (EICHHORNIA CRASSIPES) ROOTS ON SOME HEAVY METALS DISORDERS IN RATS
}

\author{
Mohamed Sabry Abdelbaky"
}

\section{Abstract}

The present study was performed to evaluate the effect of wheat germ and fermented wheat germ on some Immunoglobulin's productions, lipids profile and liver functions in cirrhotic rats by $\mathrm{Ccl} 4$. Rats were divided into eight groups , control groups (1\&2) negative and positive were fed on basal diet without supplementation. All treated cirrhotic groups (3:8) were fed on experimental diets with raw or fermented wheat germ by different levels $(5,10 \& 15 \%)$. Results clearly revealed that fermented wheat germ recorded the highest values in Vitamin (A), (E) and (C), comparing with raw wheat germ . The best treatment were fermented wheat germ $(15 \%)$ and raw wheat germ $(15 \%)$ which had lowest values of total lipid, triglycerides , total cholesterol LDL, VLDL, AST, ALT and had the highest values of HDL , respectively. While, all groups administrated fermented wheat germ by different levels $(5,10,15 \%)$ had the highest values of serum level of interferon gamma (INF-y) and interleukin -10 (IL-10) respectively . It could be concluded that wheat germ and fermented wheat germ improve some Immunoglobulin's production, lipids profile and liver functions especially fermented wheat germ 10 and $15 \%$ which has a best significant protective effect against acute hepatotoxicity induced by $\mathrm{CCl} 4$ in rats.

Key Word: fermented wheat germ - cirrhosis - CCl4 - liver oxidative stress - immune. 


\title{
EFFECT OF WATER HYACINTH (EICHHORNIA CRASSIPES) ROOTS ON SOME HEAVY METALS DISORDERS IN RATS
}

\author{
Mohamed Sabry Abdelbaky* \\ INTRODUCTION :
}

Studies confirm that heavy metals can directly influence behavior by impairing mental and neurological function, influencing neurotransmitter production and utilization, and altering numerous metabolic body processes. Systems in which toxic metal elements can induce impairment and dysfunction include the blood and cardiovascular, detoxification pathways (colon, liver, kidneys, skin), endocrine (hormonal), energy production pathways, enzymatic, gastrointestinal, immune, nervous (central and peripheral), reproductive, and urinary (Kellas and Dworkin, 1996). Lakes exposed to many pollutants including untreated sewag agricultural and industrial wastes which increase the concentration of heavy metals (lead, cadmium and mercury, fish is one of the aquatic organisms affected by heavy metals and compromise the health state of the human (Rashed,2001). Cadmium is an environmental and industrial pollutants that effects the male reproductive system of humans and animals.Cadmium administration caused an increase in reactive oxygen species (ROS) by elevating testicular malondialdehyde and decreasing the activities of testicular enzymes such as glutathion peroxidase and super oxide dismutase (Sen Gupta, et al.,2004). Lead induced oxidative stress contributes to the pathogenesis of lead poisoning for disrupting the delicate prooxidant / antioxidant balance that exists within mammalian cells, production of (ROS) is increased after lead treatment in vitro studies (Hsu and Guo,2002). The toxic metals have been documented to be reproductive and developmental toxins, causing birth defects and damaging fetal development, as well as neurological effects, developmental delays, learning disabilities, depression, and behavioral abnormalities in many otherwise normal appearing children .( Pfeiffer,2001 and William et al .,2000).

Several aquatic macrophytes have been used for the removal of heavy metals from the waste water. The use of these plants in biomonitoring of metals (Cardwell et al., 2002) or as biofilters for polluted water (Dunbabin and Bowmer, 1992), and the aspects of removal (Miretzky et al., 2004,

"Nutrition and Food Science Dept., Faculty of Home Economics, Helwan University 
Hassan et al., 2007) besides the toxicity of these metals for the plants (Drost et al., 2007) were studied. In recent years much attention has been given to wastewater treatment using the aquatic plants and recycling of the treated water. After treatment, these aquatic plants can be used for biogas production, as fiber, compost production for solid waste amendments (Haque and Sharma, 1986). Among all, the aquatic macrophytes Eichhornia crassipes, Lemna minor and Spirodela polyrhhiza have a very high growth rate and heavy metal accumulation capacity (Cardwell et al., 2002, Miretzky et al., 2004, Hassan et al., 2007). The whole plant of water hyacinth (Eichhornia crassipes) 500-600 g in 10 liters of water removes arsenic 400 $\mu \mathrm{g} / \mathrm{l}$ of arsenic completely within 3-6 hr following placement in a bucket, fibrous roots removed $81 \%$ of the arsenic; the leaves and leaf stalks removed none of the arsenic. The mechanism by which water hyacinth removed arsenic from water was by adsorption (Misbahuddin et al., 2002). More than $93 \%$ of arsenite and $95 \%$ of arsenate was removed from a solution containing arsenic $200 \mu \mathrm{g} / \mathrm{l}$ within 60 minutes of exposure to the powder of non-living dried root of water hyacinth. The concentration of arsenic remaining in solution was less than WHO guideline value of $10 \mu \mathrm{g} / \mathrm{l}$ (Rmalli et al., 2005).

The present study was carried out to illustrate the effect of water hyacinth (Eichhornia crassipes) roots and it's extract on some heavy metals disorders in rats fed on contaminated fish.

\section{Materials and Methods :}

\section{Materials:}

- Boulti fish ( Tilopia Nilotica ) was obtained from El-Manzala lake in Damiatte governorate. Each fish weighted from 400 to $450 \mathrm{gm}$.

- Male albino rats of Sprague Dawelly strain (100 \pm 5 g B.W.) were obtained from Helwan laboratory for Animals and Colonies, Ministry of Health and Population, Cairo, Egypt.

- Casein and Cellulose were purchased from Morgan Company for chemicals, Cairo, Egypt.

- Kits were purchased from Gamatrade Company, Cairo, Egypt.

- water hyacinth (Eichhornia crassipes) roots were collected from the Nile river 
Methods:

\section{Preparation of Fresh Fish:}

Fresh Boulti fish ( Tilopia Nilotica ) was cleaned and washed perfectly from external immediately after purchased, then bones, thorns and viscera were separated. After that fish was cut into similar slices of flesh fish, and dried in oven at 500c for 12 hours. Then the dried fish meat was grind to become powdered.

\section{Chemical Analysis of Powdered Fish :}

Crude protein and fat were determined in 100gm of dried fish according to the methods outlined in A.O.A.C.(1990), the results indicated that $100 \mathrm{gm}$ dried fish contain $60 \mathrm{gm}$ protein and $7.4 \mathrm{gm}$ fat .

\section{Heavy Metals Determination :}

Both treated and non treated dried fish samples were analyzed for determination heavy metals ( lead, cadmium and nickel ) according to the method described in A.O.A.C.(1995).

One gram of homogenized sample was digested in $25 \mathrm{ml}$ sulphoric acid (Conc.) when the color become clear two drops of perchloric acid have been added, complete digestion was indicated by discoloration of liquid . The flask was allowed to cool and dilution was made by added distilled water to made $50 \mathrm{ml}$ and then filtered. The filtered solution was stored at room temperature until determined by used Atomic absorption spectrophotometer ( A. Analyst 100 Apparatus ). The metal concentration were expressed as ppm metals per one gram fish tissue based on dry weight basis .

\section{Preparation of water hyacinth (Eichhornia crassipes) roots powder :}

water hyacinth (Eichhornia crassipes) roots were collected from the Nile river, washed with water and cut into small pieces and dried in oven $50^{\circ} \mathrm{C}$ until fully dried and ground by using a grinder.

\section{Preparation of diet .}

The basal diet consisted of protein $(13 \%)$, fat $(4 \%)$, salt mixture $(3.5 \%)$, vitamin mixture $(1 \%)$, choline $(0.2 \%)$, cellulose $(5 \%)$ and the remainder was starch (Reeves, et al.,1993). 


\section{Experimental Diet :}

was prepared by replacement the casein in the basal diet by powdered fish as a source of protein.

\section{Experimental design:}

A total of twenty five male healthy rats, weighing between $(100+5 \mathrm{~g})$ were divided into five groups; Each group containing 5 rats . Negative control group (1) were fed on basal diet without supplementation . Positive control group (2), fed on experimental diet which contained contaminated fish as a source of protein . Groups $(3,4 \& 5)$ fed on experimental diet which contained contaminated fish as a source of protein and supplemented with water hyacinth roots powder (WHRP) by $(2.5,5 \& 10 \%)$ respectively .

\section{Blood sampling.}

At the end of the experimental period (4weeks), rats were starved for $12 \mathrm{hr}$. , then sacrificed under ether anesthesia. Blood samples were collected from the aortic vein into clean dry centrifuge tubes and were stored at room temperature for 15 minutes, put into a refrigerator for 2 hour , then centrifuged for 10 minutes at $3000 \mathrm{rpm}$ to separate serum. Serum was carefully aspirated and transferred into dry clean Wasser -man tubes by using a Pasteur pipette and kept frozen at (-20c) till analysis .

\section{Biological Determination :}

Determination of food intake and body weight gain: Food Intake (FI) was calculated every other day, The biological value of the different diets was assessed by the determination of its effect on Body Weight Gain ratio $(\mathrm{BWG} \%)$ and organs / body weight \% at the end of the experimental period using the following formulas:

$\mathrm{BWG}=($ Final body weight - Initial body weight $) * 100$

Organ/body weight $\%=($ Organ weight $/$ Weight of rat in the end $) * 100$

\section{Chemical methods:}

Cadmium, lead and nickel were determined in serum of rat by using HPLC . 


\section{Biochemical Determination :}

\section{Determination of liver functions :}

Serum activities of aspartate amino transferase AST, alanine amino transferase ALT Alkaline Phosphatase (ALP) activities were measured according to the method described by Reitman and Frankel (1957) .

\section{Determination of kidney functions :}

Serum urea nitrogen, uric acid, creatinine were determined according to the methods described by Patton and Crouch, (1977) (22), Fossati et al., (1980) (23) and Husdan and Rapoport, (1968) (24) respectively.

\section{Histopathological Examination:}

Specimens from the liver and kidney were taken immediately after sacrificing the rats and immersed in $10 \%$ neutral buffered formalin. The fixed specimens were then trimmed, washed, and dehydrated in ascending grades of alcohol, then cleared in xylene, embedded in paraffin, sectioned at 4-6 micron thickness and stained with Hematoxylen and Eosin (Carleton, 1979) (37) and examined microscopically.

\section{Statistical Analysis :}

The obtained data were statistically analyzed according to SAS, 1996 (19).

\section{Results and discussions :}

Table (1): Heavy metals content (lead, nickel and cadmium ) of fresh fish .

\begin{tabular}{||c|c|c|c||}
\hline & $\begin{array}{c}\text { Lead (Pb) } \\
\text { ppm }\end{array}$ & $\begin{array}{c}\text { Nickel (Ni) } \\
\text { ppm }\end{array}$ & $\begin{array}{c}\text { Cadmium ( Cd) } \\
\text { ppm }\end{array}$ \\
\hline \hline Fresh fish & $10.9 \pm 3.55$ & $13.4 \pm 3.37$ & $0.19 \pm 0.04$ \\
\hline
\end{tabular}

Heavy metals concentration in fresh fish with was recorded in table (1), it could clearly revealed that fresh fish which obtained from El-Manzala lake in Damiatte governorate, Egypt, had high heavy metals contents by mean value $(10.9 \pm 3.55),(13.4 \pm 3.37)$ and $(0.19 \pm 0.04) \mathrm{ppm}$ of (lead, nickel and cadmium) respectively . 
Table (2) : Effect of water hyacinth (Eichhornia crassipes) roots powder WHRP on food intake FI and body weight gain ration $\mathrm{BWG} \%$ in rats fed on contaminated fish .

\begin{tabular}{|l|c|c||}
\hline \multicolumn{1}{|c|}{ Parameters } & FI (gm/day) & BWG\% \\
\hline \hline Croups & & \\
\hline Control (-) & 11.70 & $68.24 \pm 10.14 \mathrm{~b}$ \\
\hline Control(+) & 11.90 & $78.98 \pm 4.25 \mathrm{a}$ \\
\hline Contaminated fish with WHRP 2.5\% & 11.40 & $67.75 \pm 13.01 \mathrm{~b}$ \\
\hline Contaminated fish with WHRP 5\% & 11.30 & $64.02 \pm 9.03 \mathrm{~b}$ \\
\hline
\end{tabular}

* Values with the same letters indicate non significant difference $(\mathrm{P}<0.05)$ and vice versa.

Table (3) : Effect of water hyacinth (Eichhornia crassipes) roots powder WHRP on organs / body weight ration in rats fed on contaminated fish .

\begin{tabular}{||l|c|c|c|c|c||}
\hline \multicolumn{1}{|c|}{$\begin{array}{c}\text { Organs } \\
\text { Groups }\end{array}$} & Liver & Spleen & Kidney & Heart & Brain \\
\hline \hline Control (-) & $3.44 \pm .0 .09 \mathrm{~b}$ & $1.01 \pm 0.05 \mathrm{~b}$ & $1.24 \pm .0 .02 \mathrm{~b}$ & $0.84 \pm 0.1 \mathrm{a}$ & $1.22 \pm .0 .04 \mathrm{a}$ \\
\hline $\begin{array}{l}\text { Control(+) }+ \text { Cish } \\
\begin{array}{l}\text { Contaminated fin } \\
\text { with WHRP 2.5\% }\end{array}\end{array}$ & $3.32 \pm .0 .06 \mathrm{~b}$ & $0.89 \pm 0.04 \mathrm{~b}$ & $1.18 \pm .0 .03 \mathrm{~b}$ & $0.85 \pm 0.01 \mathrm{a}$ & $1.24 \pm .0 .04 \mathrm{a}$ \\
\hline $\begin{array}{l}\text { Contaminated fish } \\
\text { with WHRP 5\% }\end{array}$ & $3.44 \pm .0 .05 \mathrm{~b}$ & $0.98 \pm 0.04 \mathrm{~b}$ & $1.21 \pm .0 .05 \mathrm{~b}$ & $0.86 \pm 0.04 \mathrm{a}$ & $1.33 \pm .0 .04 \mathrm{a}$ \\
\hline $\begin{array}{l}\text { Contaminated fish } \\
\text { with WHRP 10\% }\end{array}$ & $3.35 \pm .0 .08 \mathrm{~b}$ & $0.90 \pm 0.03 \mathrm{~b}$ & $1.23 \pm .0 .03 \mathrm{~b}$ & $0.88 \pm 0.02 \mathrm{a}$ & $1.34 \pm .0 .07 \mathrm{a}$ \\
\hline
\end{tabular}

* Values with the same letters indicate non significant difference $(\mathrm{P}<0.05)$ and vice versa.

Table (4): Effect of water hyacinth (Eichhornia crassipes) roots powder WHRP on serum heavy metals in rats fed on contaminated fish .

\begin{tabular}{||l|l|l|l||}
\hline \multicolumn{1}{|c|}{ Parameters } & $\mathrm{Pb}(\mathrm{ppm})$ & $\mathrm{Ni}(\mathrm{ppm})$ & $\mathrm{Cd}(\mathrm{ppm})$ \\
\hline \hline Control (-) & $0.00 \pm 0.0 \mathrm{~b}$ & $0.041 \pm 0.09 \mathrm{~b}$ & $0.03 \pm 0.008 \mathrm{~b}$ \\
\hline Control(+) & $0.10 \pm 0.0 \mathrm{a}$ & $0.55 \pm 0.15 \mathrm{a}$ & $0.54 \pm 0.01 \mathrm{a}$ \\
\hline $\begin{array}{l}\text { Contaminated fish with } \\
\text { WHRP 2.5\% }\end{array}$ & $0.01 \pm 0.0 \mathrm{~b}$ & $0.054 \pm 0.17 \mathrm{~b}$ & $0.06 \pm 0.004 \mathrm{~b}$ \\
\hline $\begin{array}{l}\text { Contaminated fish with } \\
\text { WHRP 5\% }\end{array}$ & $0.00 \pm 0.0 \mathrm{~b}$ & $0.034 \pm 0.12 \mathrm{~b}$ & $0.03 \pm 0.014 \mathrm{~b}$ \\
\hline $\begin{array}{l}\text { Contaminated fish with } \\
\text { WHRP 10\% }\end{array}$ & $0.00 \pm 0.0 \mathrm{~b}$ & $0.030 \pm 0.17 \mathrm{~b}$ & $0.02 \pm 0.007 \mathrm{~b}$ \\
\hline
\end{tabular}

* Values with the same letters indicate non significant difference $(\mathrm{P}<0.05)$ and vice versa. 
Table (5): Effect of water hyacinth (Eichhornia crassipes) roots powder WHRP on serum liver function AST \& ALT in rats fed on contaminated fish .

\begin{tabular}{|l|c|c||}
\hline \multicolumn{1}{|c|}{ Parameters } & AST(U/L) & ALT (U/L) \\
\hline Groups & & \\
\hline \hline Control (-) & $80.04 \pm 1.5 \mathrm{~b}$ & $9.93 \pm 0.2 \mathrm{~b}$ \\
\hline Control(+) & $121.01 \pm 1.3 \mathrm{a}$ & $21.40 \pm 1.8 \mathrm{a}$ \\
\hline Contaminated fish with WHRP 2.5\% & $81.61 \pm 2.5 \mathrm{~b}$ & $7.53 \pm 1.6 \mathrm{~b}$ \\
\hline Contaminated fish with WHRP 5\% & $80.64 \pm 3.6 \mathrm{~b}$ & $7.92 \pm 1.8 \mathrm{~b}$ \\
\hline Contaminated fish with WHRP 10\% & $76.15 \pm 2.1 \mathrm{~b}$ & $8.42 \pm 0.2 \mathrm{~b}$ \\
\hline
\end{tabular}

* Values with the same letters indicate non significant difference $(\mathrm{P}<0.05)$ and vice versa.

\begin{tabular}{|c|c|c|c||}
\hline Groups & Urea (mg/dl) & Uric acid (mg/dl) & \\
\hline \hline Control (-) & $9.09 \pm 0.8 \mathrm{~b}$ & $2.40 \pm 0.2 \mathrm{~b}$ & $0.56 \pm 0.02 \mathrm{~b}$ \\
\hline Control(+) & $12.85 \pm 1.7 \mathrm{a}$ & $3.97 \pm 0.2 \mathrm{a}$ & $0.81 \pm 0.02 \mathrm{a}$ \\
\hline Untreated fish+ vit. E & $5.30 \pm 0.6 \mathrm{c}$ & $1.19 \pm 0.3 \mathrm{~b}$ & $0.64 \pm 0.02 \mathrm{~b}$ \\
\hline Untreated fish+ vit.E+Selenium & $6.27 \pm 0.5 \mathrm{cb}$ & $2.50 \pm 0.4 \mathrm{~b}$ & $0.61 \pm 0.02 \mathrm{~b}$ \\
\hline Treated fish 10\% EDTA+Vit C & $8.12 \pm 1.7 \mathrm{bc}$ & $2.45 \pm 0.1 \mathrm{~b}$ & $0.62 \pm 0.02 \mathrm{~b}$ \\
\hline
\end{tabular}

Conclusion: It could be concluded that
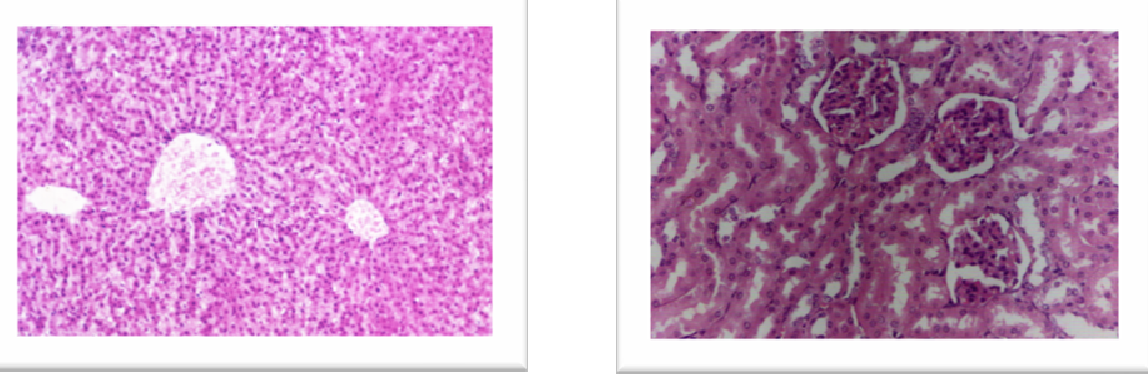

photo (1): Microscopicall examination photo (2): Microscopicall examination of of liver of rat in negative control group kidney of rat in negative control group , , showing the normal histological showing the normal histological structure structure . 

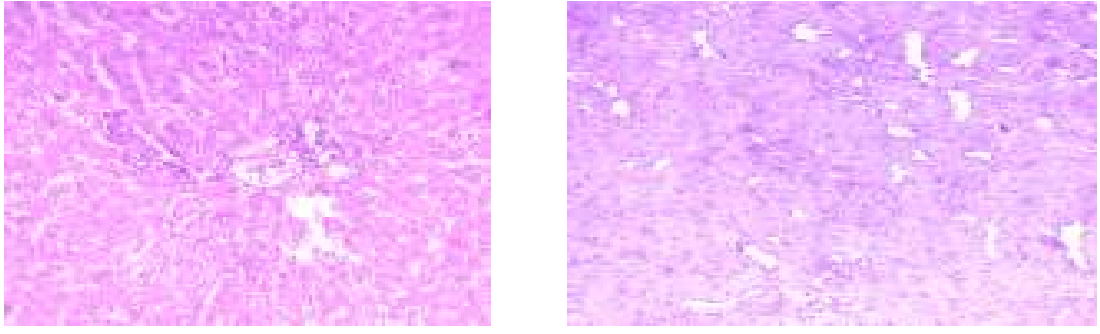

Photo (3): Microscopicall examination Photo (4): Microscopicall examination of of liver of rats fed on contaminated fish kidney of rats fed on contaminated fish without treatment WHRP showing without treatment WHRP showing mild marked hepatocytes hydropic inflammatory reaction and cloudy degeneration and portal tract with swelling of the epithelial lining of the \begin{tabular}{l|l} 
chronic inflammatory cells. & collecting tubules leading to different
\end{tabular} grades of their lumen obliteration.
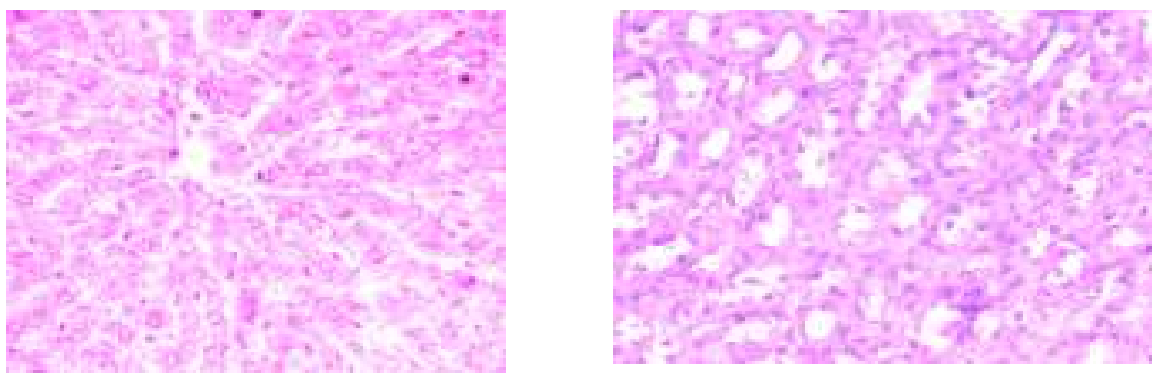

Photo (5) : Microscopicall examination Photo (6) : Microscopicall examination of liver of rats fed on contaminated fish of kidney of rats fed on contaminated with WHRP (5\%) showing mild fish with WHRP (5\%) showing mild histological alteration. $\quad$ histological alteration with patent lumens. 

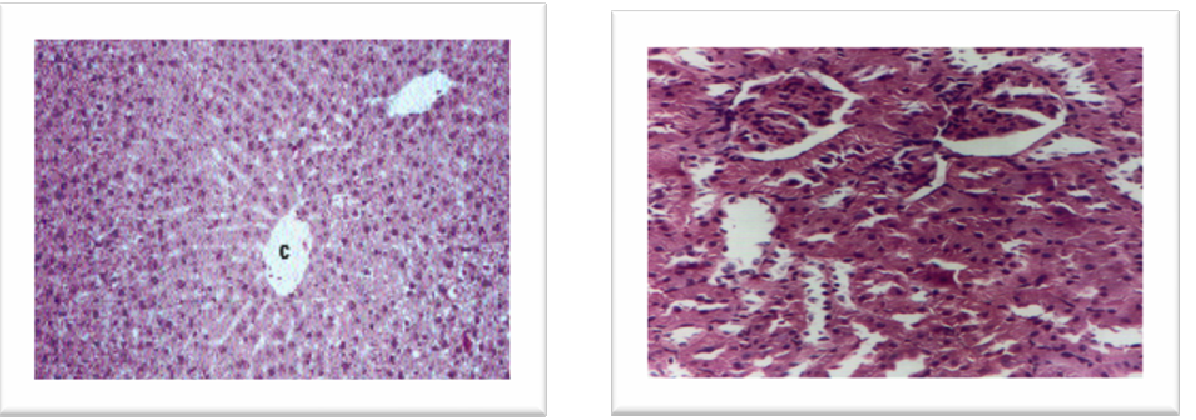

Photo (7): Microscopicall examination Photo (8): Microscopicall examination of of liver of rats fed on basal diet with kidney of rats fed on basal diet with Subcutaneous injection by $\mathrm{Ccl} 4$ and Subcutaneous injection by $\mathrm{Ccl} 4$ and administrated with BPME $(2 \mathrm{~g} / \mathrm{Kg} /$ administrated with BPME $(2 \mathrm{~g} / \mathrm{Kg} /$ day $)$ day) showing mild Degeneration showing mild histological alteration . alteration and mild swelling of hepatocytes .
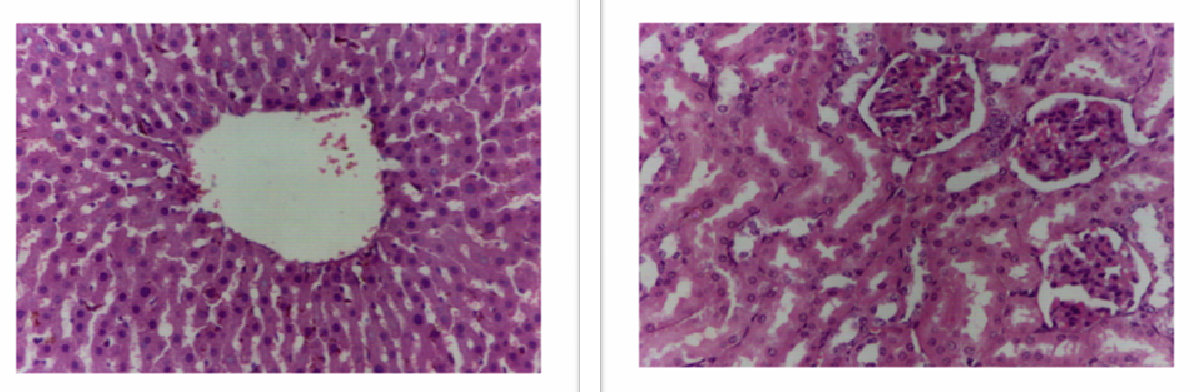

photo (9): Microscopicall examination photo (10): Microscopicall examination of liver of rat fed on basal diet with of kidney of rat fed on basal diet with Subcutaneous injection by $\mathrm{Ccl} 4$ and Subcutaneous injection by $\mathrm{Ccl} 4$ and administrated with RBPME $(2 \mathrm{~g} / \mathrm{Kg} /$ administrated with RBPME $(2 \mathrm{~g} / \mathrm{Kg} /$ day) , showing apparent normal day) , showing the normal histological histological structure. structure . 


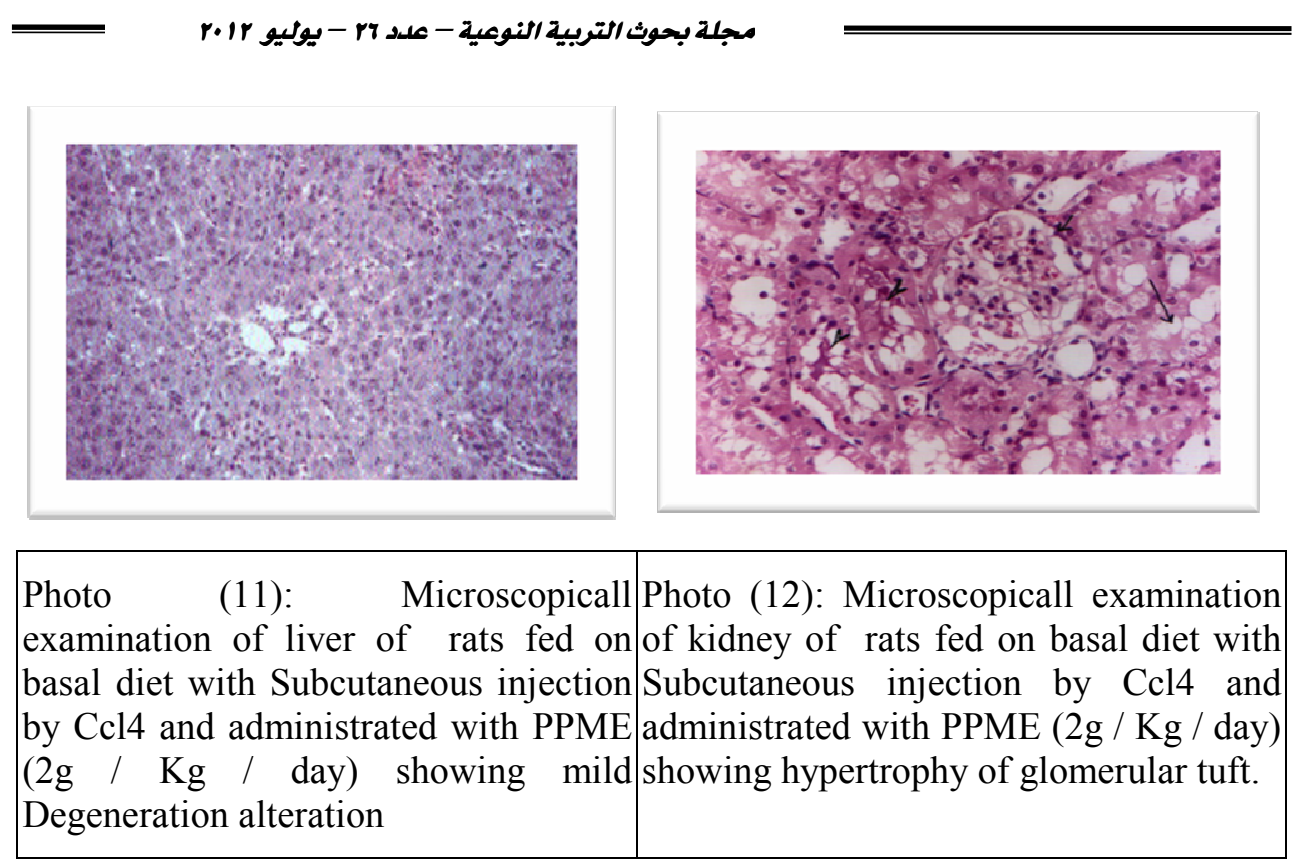




\section{References :}

- Kellas, B. and Dworkin, A. (1996): "Surviving the Toxic Crisis" (Olivenhain, CA: Professional Preference Publishing,), 186.

- Pfeiffer -HRI (2001): Center Autism Study, paper presented to Dan Conference, Jan

- Hsu, P. C. and Guo , Y. L.( 2002): "Antioxidant nutrients and lead toxicity" Toxicology, Volume 180, Issue 1, Pages 33-44

- William J. Walsh, Laura B. Glab, and Mary L. Haakenson, (2000): Pfeiffer Treatment Center, Biochemical Therapy and Behavior Outcomes,

1. H.E. Poulson, H. Prieme and S. Loft(1988). Role of oxidative DNA damage in cancer initiation and promotion, Eur J Cancer Prev 7, pp. 9-16.

2. R. Govindarajan, M. Vijayakumar and P. Pushpangadan (2005). Antioxidant approach to disease management and the role of 'Rasayana' herbs of Ayurveda, J Ethnopharmacol 99, pp. 165-178

3. Ramasamy Anandan, Balasun daram Jayakar, Biusan Karar,Seevalen Babuji, Rajappan Manavalan And Raju Senthil Kumar (2009): effect of ethanol extract of flowers of vitex trifolia linn. on ccl4 induced hepatic injury in rats .pak. j. pharm. sci., vol.22, no.4, pp.391-394

4. Nichelatti, M. and M. Hidvegi, 2002. Experimental and clinical results with Avemar (a dried extract from fermented wheat germ) in animal cancer models and in cancer patients. Nogyogyaszati Onkologia; 7: 180-185.

5. Holland, B., A.A. Welch, I.D. Unwin, D.H. Buss, A.A. Paul and D.A. Southgate, 1991. The composition of foods. The Royal Society of Chemistry Cambridge. In McCance and Widdowsons.

6. Yiqiang, G., S. Aidong, N. Yuanying and C. Tongyi, 2001. Study and development of a defatted wheat germ nutritive noodle. Eur. Food Res. Technol., 212: 344-348.

7. Sjovall, O.; Virtalaine, T.; Lapvetelainen, A.M. and Kallio, H. (2000). Development of rancidity in wheat germ analyzed by headspace gas chromatography and sensory analysis. Journal of Agricultural and Food Chemistry, 48(8): 3522-3527.

8. Liu, R. H.,(2007) . Whole grain phytochemical and health .J. Cereal Sci,46; 207-219.

9. Diplock, A. (1995). Safety of antioxidant vitamins and B-carotein, Am J Clin Nutr.,62(suppl):1510s -1516s .

10. Wood ,R. (1999). The new whole food encyclopedia. New York: Penguin Books.

11. Jayaraj, A. P. ; Tovey, F. I. ;Clork, C. g. and Hobsley, M. (2001). Gastroent. Hepatol., 16 (5), 501. 
12. USDA (2006). Oil, wheat germ, National Nutrition Database for Standard Reference, 1.

13. Reeves , P.G; Nielsen , F.H. and Fahmy , G.G. (1993). AIN-93. Purified diets for laboratory rodents : Final report of the American Institute of Nutrition adhoc wriling committee on the reformulation of the AIN-76 A Rodent diet . J. Nutrition, 123: 1939-151.

14. Wilfried,F.; Anne Bosma,F.; Hendriks,J.; Rohol,E. and Dick,.(1994). Vitamin A deficiency potentiates carbon tetrachloride induced liver fibrosis in rats., $\mathrm{J}$ of Hepathology, 19(1):193-201.

15. Allain, C.C.; Poon, L.S. and Chan, C.S., Enzymatic determination of total serum cholesterol . Clin . Chem. , .(1974) 20, 470-475.

16. Wahlefeld , A.W., Enzymatic Determination of Triglycerides .Methods of Enzymatic Analysis . .(1974)Vol. 5 , HU. Bergmeyer, Ed. Academic Press, New York, pp. 1831-1835.

17. Albers, N.; Benderson, V. and Warnick, G. ,Enzymatic determination of high density lipoprotein cholesterol : Selected Methods .Clin. Chem., (1983) 10:91-99.

18. Fridewald , W.T.; Leve, R.I. and Fredrickson , D.S .,Estimation of the concentration of low density lipoprotein . Clin. Chem. (1972) 18:499-502.

19. SAS (1996),Statistical Analysis System, ASA User's Guide : Statistics . SAS Institute Inc. Editors, Cary, NC.

20. Schmit , J.M. (1964).Colorimetric Determination of Total Lipids Using Sulfophosphovanilic Mixture . Thesis , Lyon Biomerieurx - Comp. of France .

21. Reitman,S.and Frankel,S.(1957): Determination of glutamate pyruvate transferase. Amer. J . Clin.Path.,28,32-33.

22. Patton,C.J.and Crouch,S.R.(1977):Enzymatic calorimetric method to determine urea in serum. Anal.Chem.,49,464-469.

23. Fossati,P.;Prencipe,L.and Berti,G.(1980):Enzymatic colorimetric method of determination of uric acid in serum. Clin.Chem.,26(2),227-237.

24. Husdan,H.and Rapoport,A. (1968):Estimation of creatinine by Jaffe reaction. Clin.Chem., 14,222-228.

25. Staehelin, T., Stähli, C., Hobbs, D.S., and Pestka, S. (1981) "A Rapid Quantitative Assay of High Sensitivity for Human Leukocyte Interferon with Monoclonal Antibodies," in Methods in Enzymology, Vol. 79 (S. Pestka, ed.), Academic Press, New York, 589-595.

26. Kelder, B., Rashidbaigi, A., and Pestka, S. (1986) "A Sandwich Radioimmunoassay for Human IFN- $\gamma$, " in Methods in Enzymology, Vol. 119 (S. Pestka, ed.), Academic Press, New York, 582-587.

27. Human IFN- $\gamma$ international reference standard provided by the $\mathrm{NIH}$, reference no. Gg23-901-530. Pestka, S. (1986) "Interferon Standards and General 
Abbreviations," in Methods in Enzymology, Vol. 119 (S. Pestka, ed.), Academic Press, New York, 14-23.

28. Kung, H. -F., Pan, Y.-C., Moschera, J., Tsai, K., Bekesi, E., Chang, M., Sugino, H., and Honda, S. (1986). "Purification of Recombinant Human Immune Interferon," Methods in Enzymology, Vol. 119 (S. Pestka, ed), Academic Press, New York, 204-210.

29. Croce, M.A., et al. (1998). Partial liquid ventilation decreases the inflammatory response in the alveolar environment of trauma patients. J. Trauma 45, 273-282.

30. Greig, P., et al. (1995). Elevated amniotic fluid interleukin-10 concentrations increase through pregnancy are elevated in patients with preterm labor associated with intrauterine infection. Amer. J. Obstet. Gynecol. 173, $1223-1227$.

31. Komorowski, J., et al. (1998). Cytokine serum levels as the markers of thyroid activation in Graves' disease. Immunol. Lett. 60, 143-148.

32. Koziel, M.J., et al. (1995). HLA class I-restricted cytotoxic T lymphocytes specific for hepatitis $\mathrm{C}$ virus. Identification of multiple epitopes and characterization of patterns of cyokine release. J. Clin. Invest. 96, 2311-2321.

33. Platz, K., et al. (1996). Cytokine pattern during rejection and infection after liver transplantation - improvements in postoperative monitoring? Transplantation 62, 1441-1450.

34. Schultze, J.L., et al. (1997). CD40-activated human B cells: an alternative source of highly efficient antigen presenting cells to generate autologous antigen- specific $\mathrm{T}$ cells for adoptive immunotherapy. J. Clin. Invest. 100, 2757-2765.

35. Whitcup, S.M., et al. (1997). Association of interleukin 10 in the vitreous and cerebrospinal fluid and primary central nervous system lymphoma. Arch. Ophthalmol. 115, 1157-1160.

36. Zhang, Y., et al. (1997). Secretory leukocyte protease inhibitor suppresses the production of monocyte prostaglandin $\mathrm{H}$ synthase-2, prostaglandin $\mathrm{E} 2$, and matrix metalloproteinases. J. CLin. Invest. 99, 894-900.

37. Carleton,H.(1979). Histological Techniques 4th Ed. London, Oxford University press ,New York, Toronto .

38. Klimes, J.; Jedlicka, A.; Determination of Water- and Fat-Soluble Vitamins in Different Matrices UsingHigh-Performance Liquid Chromatography,Chem. Pap., 2005, 59, 202-222.

39. Ranjbar, A.H., F.J. Solhi, A. Mashayekhi and M. Abdollahi, 2005. Oxidative stress in acute human poisoning with organophosphorus insecticides; a case control study. Environ. Toxicol. Pharmacol., 20: 88-91.

40. Abdollahi, M., A. Ranjbar, S. Nikfar and A. Rezaie, 2004. Pesticides and oxidative stress a review. Med. Sci. Monit., 10: 141-147. 
41. Gupta, R.C., 2006. Toxicology of Organophosphates and Carbamate Compounds. Elsevier Academic Press,USA, London, UK.

42. Vaher, M., K. Matso, T. Levandi and M. Kaljurand, 2010. Phenolic compounds and the antioxidant activity of the bran, flour and whole grain of different wheat varieties. Procedia Chem., 2: 76-82.

43. Ge, Y., A. Sun, Y. Ni and T. Cai, 2001. Study and development of a defatted wheat germ nutritive noodle. European Food Res. and Techn., 212: 344-348.

44. Zhu, K., H.M. Zhou and H.F. Qian, 2006. Proteins extracted from defatted wheat germ, nutritional and structural properties. Cereal Chem., 83: 69-75.

45. Mansour, S.A. and A.H. Mossa, 2010. Adverse effects of exposure to low doses of chlorpyrifos in lactating rats. Toxicol Ind Health., 27(3): 213-224.

46. Gregorio, S.R., M.A. Areas and F.G. Reyes, 2001. Dietary 93. Rodent diet. J. Nutr., 123: 1939-1951. fibers and cardiovascular disease. 22: 109-120.

47. Borel P, Lairon D, Senft M, Chautan M, Lafont H. Wheat bran and wheat germ: effect on digestion and intestinal absorption of dietary lipids in the rat. Am J Clin Nutr 1989;49:1192-202.

48. Lairon D, Lacombe C, Borel P, et al. Beneficial effect of wheat germ on circulating lipoproteins and tissue lipids in rats fed a high cholesterolcontaining diet. J Nutr 1987;117:838-45.

49. Cara L, Dubois C, Borel P, et al. Effects of oat bran, rice bran, wheat fiber, and wheat germ on postprandial lipemia in healthy adults. Am J Clin Nutr 1992;55:81-8.

50. Lairon D, Borel P, Termine E, Grataroli R, Chabert C, Hauton JC. Evidence for a proteinic inhibitor of pancreatic lipase in cereals, wheat bran and wheat germ. Nutr Rep Int 1985;32:1107-13.

51. Cara L, Borel P, Armand M, et al. Effects of increasing levels of raw or defatted wheat germ on liver, feces and plasma lipids and lipoproteins in the rat. Nutr Res 1991;11:907-16.

52. Cesare Alessandri, Pasquale Pignatelli, Lorenzo Loffredo, Luisa Lenti, Maria Del Ben, Roberto Carnevale, Alessandro Perrone, Domenico Ferro, Francesco Angelico, Francesco Violi ,(2006). Alpha-Linolenic Acid-Rich Wheat Germ Oil Decreases Oxidative Stress and CD40 Ligand in Patients With Mild Hypercholesterolemia. Arterioscler Thromb Vasc Biol , 26:2577-2578.

53. El-Khayat, Z., R.E. Ahmed, S.A. Mahmoud, I.R. Wafaa and R.E. Tahany, 2009. Potential effects of bee honey and propolis against the toxicity of ochratoxin A in rats. Maced. J. Med. Sci., 2(4): 311-318.

54. Pari, L. and S. Arumugam, 2008. Effect of grape (Vitis vinifera L.) leaf extract on alcohol induced oxidative stress in rats. Food and Chemical Toxicol., 46: 1627-1634.

55. Li, L. and J. Zhong, 2004. Effect of grape procyanidins on the apoptosis and mitochondrial transmembrane potential of thymus cells. J. of Hygiene Res., 33: 191-194. 
56. Yuguang, L., R. Mike, A. Trautwein and W. Gert, 2004. Wheat Germ Policosanol failed to lower plasma cholesterol in subjects with normal to mildly elevated cholesterol concentrations. Metabolism., 53: 1309-1314.

57. Liu, R. H.,(2007) ;Whole grain phytochemical and health .J. Cereal Sci,46; 207-219.

58. Bowers, J. (2002) : Nutrition and immunity, You Are What You Eat. Vol. 11, No. 2.

59. Scrimshaw, N. (1997) : Synergism or nutrition, infection and immunity: an overview", Am J Clin Nutr., 8(4): 177-83.

60. Meydani, S. (1996) : Effect of (n-3) polyunsaturated fatty acids on cytokine production and their biologic function, Nutrition, 12:S8-S14.

61. Bendich, A. (1990): Antioxidant vitamins and their functions in immune responses. Adv Exp Med Biol, 262:35-55.

62. Abdel Ghafar,N. M. (2004) : Effect of Zinc and vitamin E on immune system of rats. Ph. D Thesis,Faculty of Home Economic, Helwan University.

63. Moriguchi, S. and Muraga, M.(2000): vitamin E and immunity, Vitamin Horm, $59: 305-36$.

64. Meydani, S. N; Barklund, M. P ;Liu, S.; Meydani, M. ;Miller, R.A.; Cannon, J.G.; Morrow, F.D.; Rocklin, R . and Blumberg, J.B.(1990) : Vitamin E supplementation enhances cell-mediated immunity in healthy elderly subjects. Am J Clin Nutr ,52:557-63.

65. De Waart, F. G, Portengen L, and Doekes G.(1997):Effect of 3 months vitamin E supplementation on indices of the cellular and humoral immune response in elderly subjects. Br J Nutr, 78:761-74.

66. Chew, B.P. (1993) :Role of carotenoids in the immune response. J Dairy Sci.; 76: 2804-11.

67. Abu-Tarboush, H.M. and Ahmed, S.B. (1996): Studies on Karkade (Hibiscus sabdariffa): protease inhibitors, phytate, in vitro protein digestibility and gossypol content. Food Chem., 56, 15.

68. Hassan, I.A.G. and EI-Tinay, A.H. (1995): Effect of fermentation on tannin content and in vitro protein and starch digestibilities of two sorghum cultivars. Food Chern, 53, 149.

69. Boros, L. G; Nichelatti, M and Shoenfeled Y. (2005): Fermented wheat germ extract (Avemar) in the treatment of cancer and autoimmune diseases, Ann. N. Y. Acad Sci. Jum. 1051: 529-42. 